\title{
Human ribosomal protein L13a is dispensable for canonical ribosome function but indispensable for efficient rRNA methylation
}

\author{
SUJAN CHAUDHURI, ${ }^{1}$ KEYUR VYAS, ${ }^{1}$ PURVI KAPASI, ${ }^{1}$ ANTON A. KOMAR, ${ }^{1}$ JONATHAN D. DINMAN, ${ }^{2}$ \\ SAILEN BARIK, ${ }^{3}$ and BARSANJIT MAZUMDER ${ }^{1}$ \\ ${ }^{1}$ Department of Biological, Geological and Environmental Sciences, Cleveland State University, Cleveland, Ohio 44115, USA \\ ${ }^{2}$ Department of Cell Biology and Molecular Genetics, University of Maryland, College Park, Maryland 20742, USA \\ ${ }^{3}$ Department of Biochemistry and Molecular Biology, University of South Alabama, College of Medicine, Mobile, Alabama 36688, USA
}

\begin{abstract}
Previously, we demonstrated that treatment of monocytic cells with IFN- $\gamma$ causes release of ribosomal protein L13a from the $60 \mathrm{~S}$ ribosome and subsequent translational silencing of Ceruloplasmin (Cp) mRNA. Here, evidence using cultured cells demonstrates that Cp mRNA silencing is dependent on L13a and that L13a-deficient ribosomes are competent for global translational activity. Human monocytic U937 cells were stably transfected with two different shRNA sequences for L13a and clonally selected for more than $98 \%$ abrogation of total L13a expression. Metabolic labeling of these cells showed rescue of $\mathrm{Cp}$ translation from the IFN- $\gamma$ mediated translational silencing activity. Depletion of L13a caused significant reduction of methylation of ribosomal RNA and of cap-independent translation mediated by Internal Ribosome Entry Site (IRES) elements derived from p27, p53, and SNAT2 mRNAs. However, no significant differences in the ribosomal RNA processing, polysome formation, global translational activity, translational fidelity, and cell proliferation were observed between L13a-deficient and wild-type control cells. These results support the notion that ribosome can serve as a depot for releasable translation-regulatory factors unrelated to its basal polypeptide synthetic function. Unlike mammalian cells, the L13a homolog in yeast is indispensable for growth. Thus, L13a may have evolved from an essential ribosomal protein in lower eukaryotes to having a role as a dispensable extra-ribosomal function in higher eukaryotes.
\end{abstract}

Keywords: L13a; translation; ribosome biogenesis; polysome; translational fidelity; rRNA methylation; IRES activity

\section{INTRODUCTION}

Ribosomes are complex macromolecular machines composed of rRNAs and proteins and are responsible for the synthesis of polypeptide chains in all living cells. Atomic resolution crystal structures of prokaryotic ribosome suggest that the two fundamental activities of ribosome, i.e., peptidyl transfer at the $\mathrm{P}$ site and decoding activity at the A site, are carried out by the RNA (Ban et al. 2000; Nissen et al. 2000; Ogle et al. 2001). Structural analysis of the large ribosomal subunit revealed that most of the protein mass is present as discrete globular domains on the surface of the rRNA and far from the site of catalysis. Many ribosomal

Reprint requests to: Barsanjit Mazumder, Department of Biological, Geological and Environmental Sciences, Cleveland State University, Cleveland, OH 44115, USA; e-mail: b.mazumder@csuohio.edu; fax: (216) 687-2932.

Article published online ahead of print. Article and publication date are at http://www.rnajournal.org/cgi/doi/10.1261/rna.694007. proteins also have extended tails that protrude into the bodies of the subuints, and these are believed to provide structural support to the rRNA (Cech 2000). A comparable picture is also emerging from lower resolution structural studies of eukaryotic ribosomes (Spahn et al. 2001; Sharma et al. 2003). Some ribosomal proteins with extended loops, e.g., L2, L3, L4, L10, L11, and L22, are located near regions of functional importance, such as the polypeptide exit tunnel and the factor-binding site (Brodersen and Nissen 2005; Wilson and Nierhaus 2005). However, other surface proteins lacking RNA-penetrating tails appear to float on the rRNA surface, and their roles in ribosome function remain enigmatic.

Many reports have demonstrated that certain ribosomal proteins can carry out tasks often unrelated to the protein synthesis activity of the ribosome (for review, see Wool 1996). For example, ribosomal protein L26 activates the translation of p53 mRNA (Takagi et al. 2005), L23 and L11 can regulate HDM2 activity (Lohrum et al. 2003; Jin et al. 
2004; Dai et al. 2004), and L41 can suppress cell growth (Yoo et al. 2005). Using an IFN- $\gamma$ stimulated human monocytic cell line U937, we previously demonstrated that the entire cellular pool of L13a was phosphorylated and released from the $60 \mathrm{~S}$ ribosomal subunit. The released L13a specifically bound to the gamma activated inhibitor of translation (GAIT) element present in the $3^{\prime}$-UTR of ceruloplasmin (Cp) mRNA, silencing its translation (Mazumder et al. 2003). This silencing relies on a mechanism in which P-L13a, as a part of the $3^{\prime}$-UTR bound GAIT complex, can compete with 43S-bound eIF3 for binding to cap-bound eIF4G (Kapasi et al. 2007).

Insights into the possible mechanisms of L13a release from the $60 \mathrm{~S}$ ribosome can be gained from an inspection of the bacterial homolog of mammalian L13a in the crystal structure of the prokaryotic ribosome (Ban et al. 2000). Prokaryotic L13 (homolog of mammalian L13a) is a globular protein resting on the surface of the 50S subunit without any submerged or anchoring domains and with minimal contact with nearby ribosomal proteins (Mazumder et al. 2003). There is no comprehensive study of the role of any such surface ribosomal proteins in ribosome function of mammalian cells. The current study employed shRNA mediated knockdown of L13a to show that silencing of L13a in human monocytic cells abrogates IFN- $\gamma$ mediated inhibition of Cp mRNA translation. Surprisingly, silencing of L13a in U937 cells did not affect global protein synthesis, biogenesis of $60 \mathrm{~S}$ ribosomes, translational fidelity, and assembly of the $80 \mathrm{~S}$ ribosomes or polyribosomes. Targeted knockdown of ribosomal protein L13a provides an opportunity to directly address the role of L13a on ribosomal activity.

\section{RESULTS}

\section{Generation of L13a knocked down monocytic cells}

Nucleotide positions 460-478 and 147169 of the L13a ORF were selected as 19-nt target sequences following published guidelines (Elbashir et al. 2001;
Musiyenko et al. 2007). Synthetic sense and antisense oligonucleotides encoding the shRNAs (Fig. 1A) were annealed and cloned into the lentiviral vector pLU6EGFP (Fig. 1B). Recombinant lentivirus harboring the target
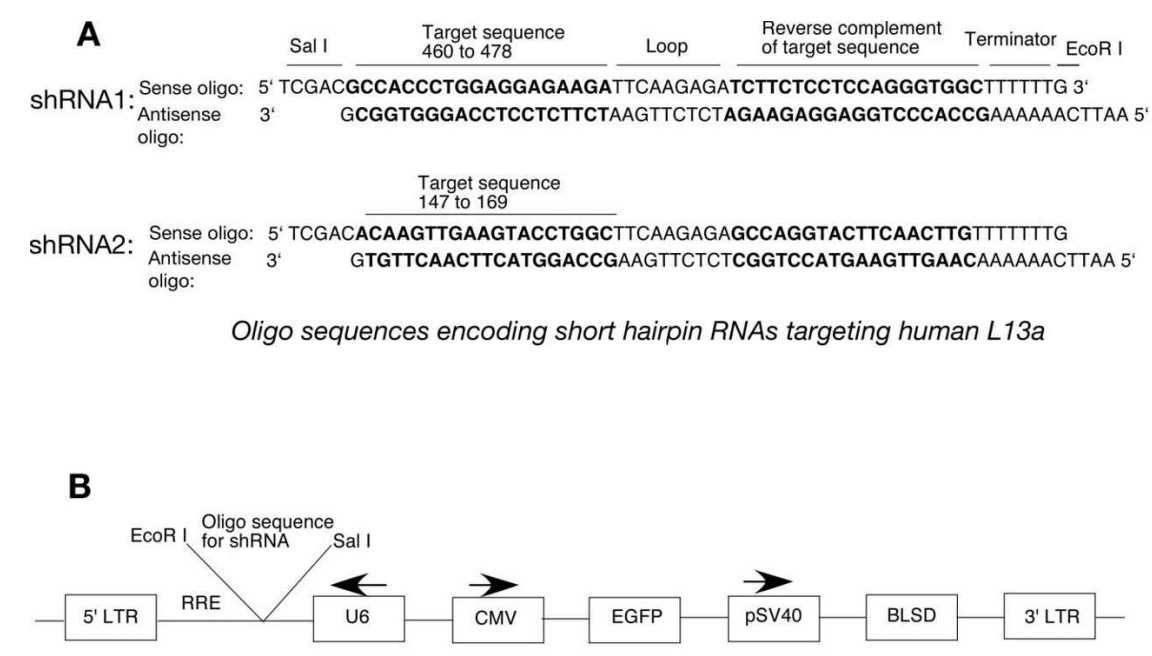

Design of lentiviral vector for transduction of shRNA
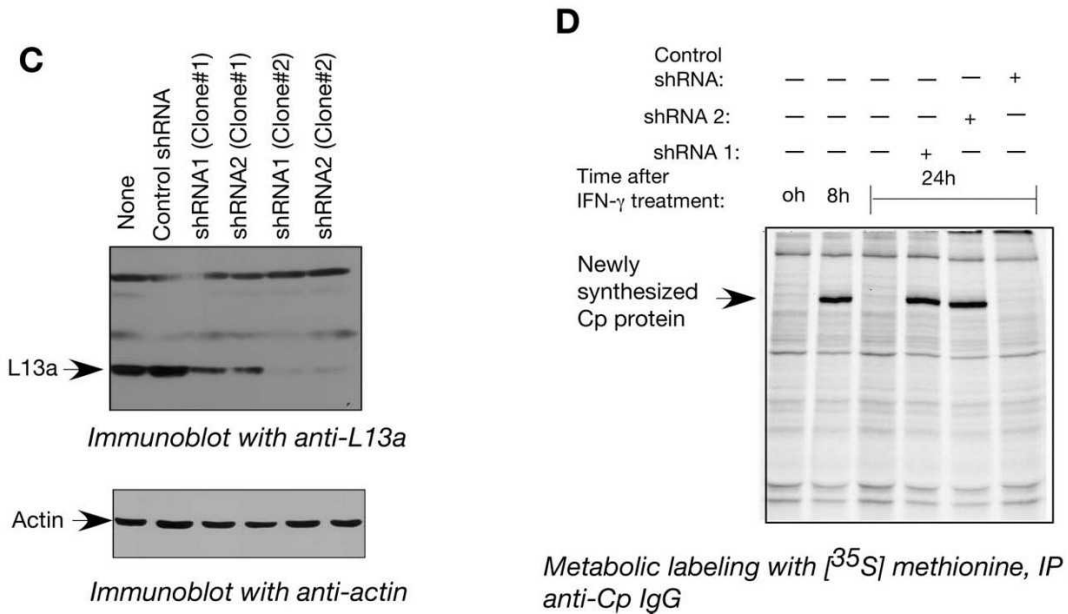

Metabolic labeling with ${ }^{35} S /$ methionine, IP with anti-Cp IgG

FIGURE 1. Generation of L13a-depleted U937 monocytic cells by stable expression of shRNA. (A) Designs for the shRNA1 and shRNA2 for targeted depletion of endogenous L13a by RNA silencing. (B) Design of the vector for making the recombinant lentiviruses harboring shRNA sequence against L13a. (C) Identification of single U937 cell clones with abrogated expression of endogenous L13a by immunoblot analysis. U937 cells expressing L13a shRNA1, shRNA2, or control shRNA were made by lentivirus-mediated transduction. Transduced cells were clonally purified by serial dilution and selected in blasticidin. Abrogation of L13a expression was tested by immunoblot analysis of $100 \mu \mathrm{g}$ of the total lysate with anti-L13a (upper panel) and reprobed with anti-actin antibody (lower panel) as a control. (D) Abrogation of L13a rescues Cp translation from IFN- $\gamma$ mediated translational silencing. U937 cells expressing shRNA1, shRNA2, or control shRNA were treated with IFN- $\gamma$ for 0,8 , or $24 \mathrm{~h}$. At the end of each interval cells were metabolically labeled by incubation with $\left[{ }^{35} \mathrm{~S}\right]$-methionine in methioninefree medium for $2 \mathrm{~h}$. Lysates were subject to immunoprecipitation (IP) with rabbit anti-human $\mathrm{Cp}$ IgG and resolved by SDS-PAGE. The radiolabeled bands were detected by autoradiography on X-ray film. The whole image comes from a single gel run and a single experiment, but a duplicate and identical shRNA2 lane was deleted. 
shRNA sequences (shRNA1 and shRNA2) and control shRNA were made from this vector and used to transduce U937 cells (see Materials and Methods for details). Cells were stably transduced with the recombinant lentivirus and clonally selected by serial dilution and selection in blasticidin. Individual clones were then tested for expression of EGFP and functional L13a shRNAs by immunoblot analysis with anti-L13a antibody. Two clones each (Clones \#1 and \#2) were isolated for shRNA1 and shRNA2. Immunoblot analysis (Fig. 1C, upper panel) shows that Clone \#1 for both shRNA1 and shRNA2 exhibits 50\% reduction of L13a compared to control shRNA and that Clone \#2 exhibits $\sim 98 \%$ reduction. Reprobing with anti-actin antibody showed no change in actin expression, demonstrating the target specificity of the shRNAs (Fig. 1C, lower panel). Subsequent experiments used the shRNA1 and shRNA2 Clone \#2 cell lines, denoted as shRNA1 and shRNA2. The same lentiviral constructs were also transduced into 293T cells, and clonally selected cells that stably express shRNA1 and shRNA2 showing $\sim 95 \%$ reduction of L13a were also generated (data not shown). The effective depletion of this protein from the polyribosomal fraction has also been confirmed and shows immunologically undetected level of L13a (Supplement Fig. 1, available upon sending an e-mail message containing the keyword "supple_Fig. 1_L13a siRNA” to b.mazumder@csuohio.edu).

\section{Abrogation of L13a overcomes IFN- $\gamma$ mediated silencing of $\mathrm{Cp}$}

L13a was previously identified as an essential component of the GAIT complex, capable of silencing Cp translation (Mazumder et al. 2003; Sampath et al. 2004). U937 cells stably expressing the shRNA of L13a and showing abrogation of L13a expression were employed in the current study to test the in vivo role of L13a in translational silencing. Wild-type U937 cells were induced by IFN- $\gamma$ and de novo synthesis of $\mathrm{Cp}$ was measured by pulse labeling with $\left[{ }^{35} \mathrm{~S}\right]$ methionine followed by immunoprecipitation with anti-Cp antibody. Consistent with previous observations (Mazumder and Fox 1999), Cp protein synthesis in U937 cells ceased after $\sim 16 \mathrm{~h}$ of IFN- $\gamma$ treatment. However, complete restoration of $\mathrm{Cp}$ protein synthesis from the IFN$\gamma$-mediated silencing activity was observed when cells expressing shRNA of L13a were used (Fig. 1D). These results demonstrate the in vivo requirement of $\mathrm{L} 13 \mathrm{a}$ in the IFN- $\gamma$-mediated silencing of Cp translation.

\section{Ribosome biogenesis is unaffected in L13a deficient cells}

Studies in yeast have shown that one or more steps of prerRNA processing are blocked and cells accumulate prerRNPs upon depletion or inactivation of certain ribosomal proteins (e.g., S14, L11) (Moritz et al. 1990; Kressler et al.
1999; Harnpicharnchai et al. 2001; Jakovljevic et al. 2004). However, no comparably detailed study on the role of ribosomal protein(s) in ribosome biogenesis has been performed in higher eukaryotes. The human monocytic cell lines generated in this study enabled us to monitor the effects of L13a deficiency on ribosome biogenesis in metazoan cells.

Assembly and maturation of eukaryotic ribosomes takes place in the nucleolus, where the $35 \mathrm{~S}-47 \mathrm{~S}$ primary rRNA transcript associates with a number of ribosomal proteins and other trans-acting assembly factors to form the $90 \mathrm{~S}$ pre-rRNP. This serves as the substrate for a series of endoand exonucleolytic digestions that ultimately generate $60 \mathrm{~S}$ and 40S ribosomal subunits (Warner 2001; FromontRacine et al. 2003; Tschochner and Hurt 2003). To directly assess the effect of L13a deficiency on the accumulation of 40S, 60S, and 90S pre-ribosomes, nuclear extracts made from the L13a-deficient cells (shRNA1 and shRNA2) and from controls (nontransduced and scrambled shRNA transduced) were fractionated by sucrose gradient centrifugation. No differences were found in the nuclear accumulation of the $90 \mathrm{~S}$ pre-ribosomes (Fig. 2A). To check the authenticity of the $90 \mathrm{~S}$ preribosome, RNAs were isolated from $90 \mathrm{~S}$ and $80 \mathrm{~S}$ fractions obtained from nuclear and post-nuclear lysates. RT-PCR amplification was carried out using primers corresponding to the different regions of the unprocessed 47S rRNA (Fig. 2B, right panel), the primary constituent of $90 \mathrm{~S}$ pre-ribosome. The primer pair from the $5^{\prime}$ external transcribed spacer ( $5^{\prime}$ ETS) region that is only present in unprocessed rRNA was able to amplify the product of the expected size when the RNA from the 90S peak fractions was used. On the other hand, no product was obtained using the same primers and the RNA isolated from the $80 \mathrm{~S}$ peak. Similarly, the amplification product of the expected size was obtained using the RNA isolated from the $90 \mathrm{~S}$ peak fractions when one primer from the $5^{\prime}$ ETS region and the other from the $18 \mathrm{~S}$ region were used (Fig. $2 \mathrm{~B}$, left panel). These results confirmed the presence of unprocessed rRNA in the $90 \mathrm{~S}$ pre-ribosome peak.

It is possible that nuclear accumulation of pre-ribosomes remained unaffected in L13a-deficient cells, but there might be a defect in processing or turnover of $47 \mathrm{~S}$ pre-rRNA (Sugimoto et al. 2003). It has been reported that inactivation of the S6 protein of small ribosomal subunit causes inhibition of pre-rRNA processing in T lymphocytes (Sulic et al. 2005) and liver (Volarevic et al. 2000). To address the possibility of pre-rRNA processing defects, the L13adeficient cells were metabolically labeled with a short pulse of $\left[{ }^{3} \mathrm{H}\right]$-uridine followed by chase without the radioactive precursor, and samples were collected at specified time points. Processing of the de novo synthesized pre-rRNA was observed following the major pre-rRNA intermediates in the processing pathway, e.g., 47S, 41S, 36S, 32S, and the mature $28 \mathrm{~S}$ and $18 \mathrm{~S}$. No significant difference was observed in their rate of appearance or disappearance of the processing 
A

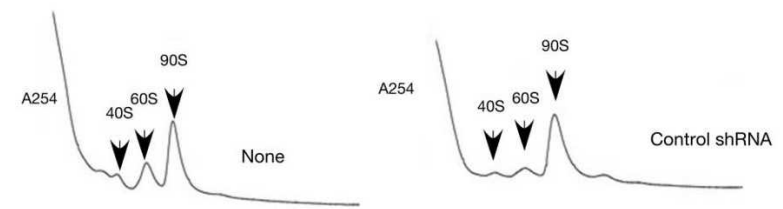

B
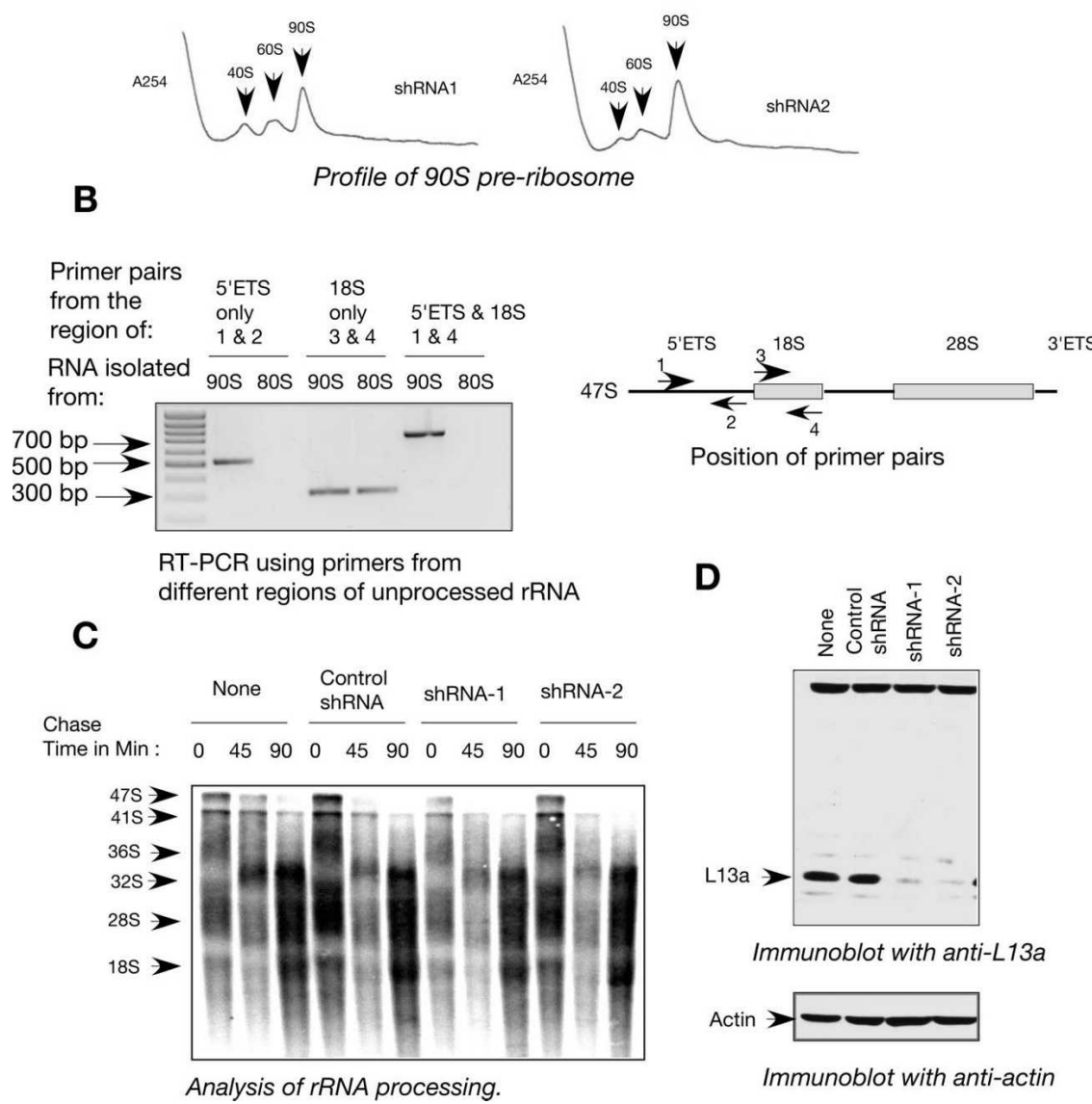

FIGURE 2. Depletion of L13a does not alter ribosome biogenesis. (A) Abrogation of L13a by RNA silencing does not alter $90 \mathrm{~S}$ pre-ribosome formation. Nuclear extracts were prepared from U937 cells expressing shRNA1, shRNA2, control shRNA, or untransduced cells. The extracts were layered over $10 \%-40 \%$ sucrose gradients and resolved by centrifugation. After centrifugation the fractions were unloaded by upward displacement using an ISCO gradient fractionation system. UA-6 UV detector recorded continuous OD readout at A254. The presence of $90 \mathrm{~S}$ pre-ribosomes was detected by the indicated peak. (B) Authenticity of the $90 \mathrm{~S}$ pre-ribosome fraction. Total RNA was isolated from the 90S peak fractions obtained from nuclear lysate and 80 S peak fractions obtained from post-nuclear lysate of U937 cells. The RNA was subjected to RT-PCR amplification using primers made against the $5^{\prime}$ external transcribed spacer (ETS) and $18 \mathrm{~S}$ sequence present in the unprocessed 47S rRNA (left panel). The amplification products of the expected size were observed (right panel). (C) Abrogation of L13a by RNA silencing does not alter ribosomal RNA processing. U937 cells expressing shRNA1, shRNA2, or control shRNA were pulse labeled with $\left[{ }^{3} \mathrm{H}\right]$-uridine for $1 \mathrm{~h}$ followed by chase in nonradioactive medium for 0,45 , or $90 \mathrm{~min}$. RNAs were extracted at the end of indicated chase period, resolved, and transferred to Hybond $\mathrm{N}+$ membrane (Amersham). Dried membranes were subjected to autoradiography. Turnover of the $47 \mathrm{~S}$ precursor rRNA to the processed and matured $28 \mathrm{~S}$ and $18 \mathrm{~S}$ rRNA was observed. (D) Maintenance of the effective L13a depletion in the cells used in the above experiments. The depletion of L13a was verified by immunoblot analysis of $100 \mu \mathrm{g}$ of the total cell lysates made from the wild-type U937 cells or cells expressing shRNA1, shRNA2, or control shRNA with anti-L13a antibody (upper panel). For loading control the same blot was reprobed with anti-actin antibody (lower panel). intermediates with different chase time between the controls and L13a-depleted cells (Fig. 2C). Maintenance of the effective depletion of L13a has been confirmed by immunoblot analysis using the anti-L13a antibody (Fig. 2D).

\section{Reduced methylation of $47 \mathrm{~S}$ pre-rRNA in L13a-deficient cells}

Nascent pre-rRNA undergoes a series of modifications including methylation at the 2'-O ribose position (Kiss-Laszlo et al. 1996; Bachellerie and Cavaille 1997). The role of this modification in ribosome assembly and function remains speculative. To examine the requirement of L13a in pre-rRNA methylation, L13a-depleted U937 cells were metabolically labeled with a short pulse of [methyl- ${ }^{3} \mathrm{H}$ ]-methionine (Sugimoto et al. 2003). Significant reduction in the level of methylation of $47 \mathrm{~S}$ pre-rRNA was observed in L13a-deficient cells (Fig. 3, upper panel). To rule out the possibility that the methylation defect could be due to a defect in the rate of rRNA synthesis, L13a-deficient cells were metabolically labeled by $\left[{ }^{3} \mathrm{H}\right]$-uridine. No differences were observed between the L13a-deficient and control cells in either $\left[{ }^{3} \mathrm{H}\right]$-uridine incorporation (Fig. 3 , middle panel) or in the steady-state levels of $28 \mathrm{~S}$ and 18S rRNA (Fig. 3, lower panel). To test whether the dependence of rRNA methylation on L13a is specific for U937 monocytic cells only, we tested rRNA methylation in human embryonic kidney 293T cells similarly depleted of L13a by lentiviral RNAi and observed essentially identical loss of methylation (data not shown). Together, these results demonstrate that depletion of L13a causes significant reduction of pre-rRNA methylation without affecting pre-rRNA synthesis.

\section{Polysome profiles, total protein synthesis, and cell proliferation are normal in L13a-deficient cells}

The experiments described above show that pre-rRNA processing, which is a nucleolar event, is not affected by L13a deficiency. However, L13a could 


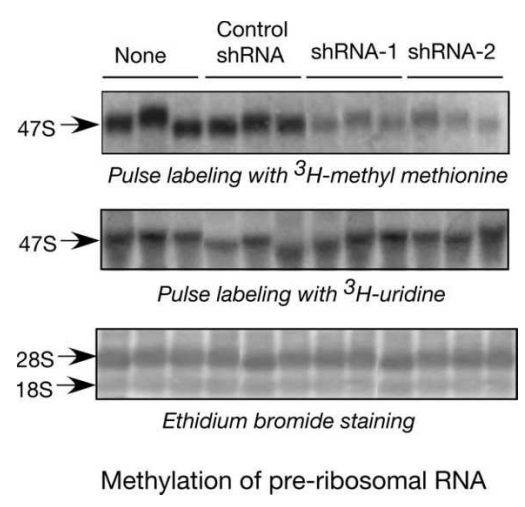

FIGURE 3. Depletion of L13a significantly inhibits the methylation of rRNA. U937 cells expressing shRNA1, shRNA2, or control shRNA were pulse labeled with [methyl- $\left.{ }^{3} \mathrm{H}\right]-$ methionine for $1 \mathrm{~h}$. At the end of the pulse period RNA was extracted, resolved, and transferred to Hybond N+ membrane (Amersham). Dried membranes were subjected to autoradiography. Methylation of newly synthesized rRNA is shown by incorporation of radioactive methyl methionine (upper panel). Total rRNA synthesis was determined as a control by pulse labeling the same cells in parallel by $\left[{ }^{3} \mathrm{H}\right]$-uridine (middle panel). Steady-state levels of $28 \mathrm{~S}$ and $18 \mathrm{~S}$ rRNA were determined by ethidium bromide staining of the membrane from the methylation experiment (lower panel).

potentially have a role in the cytoplasmic compartment, where mature $40 \mathrm{~S}$ and $60 \mathrm{~S}$ ribosomes come together to make the elongation competent $80 \mathrm{~S}$ complex followed by the formation of active polysomes on the translating pool of cellular mRNA. Thus, it is possible that L13a deficiency can affect translation without influencing the processing of rRNA in the nucleolus.

Sucrose gradient analysis of cytoplasmic extracts made from L13a-deficient and wild-type control cells was used to investigate whether L13a deficiency and the subsequent defect in pre-rRNA methylation (Fig. 3) might directly affect ribosomal translational competence. No significant differences in polysome formation or in the pools of free $40 \mathrm{~S}, 60 \mathrm{~S}$, or $80 \mathrm{~S}$ ribosomes were observed between the two sets of extracts (Fig. 4A). If L13a played an essential role in the process of protein synthesis, its depletion would have caused not only a reduction in the number of polysomes, but also a simultaneous increase in the pool of free 40S, $60 \mathrm{~S}$, and $80 \mathrm{~S}$ ribosomes. In a parallel experiment, metabolic labeling of the L13a-depleted U937 cells with $\left[{ }^{35} \mathrm{~S}\right]$ methionine showed no significant differences between wild-type and L13a-depleted cells in the amounts of incorporated radioactivity (Fig. 4B). The maintenance of effective L13a depletion has been verified by immunoblot analysis (Fig. 4C). Together, these data show that depletion of L13a does not significantly affect the global protein synthesis activity of ribosomes.

The ability to form active polysomes and unfettered ribosome synthesis is absolutely required for cell proliferation. Reciprocally, cells that exit the cell cycle and attain a quiescent state exhibit greatly reduced ribosome produc- tion and overall protein synthesis (Pardee 1989; Lewis and Tollervey 2000; Ruggero and Pandolfi 2003). There are conflicting reports in the literature about the role of ribosomal protein L13a on cell growth and apoptosis (Chen et al. 1998; Chen and Ioannou 1999; Kobayashi et al. 2006). Rates of cell growth comparing the L13a-depleted versus wild-type controls were performed by measuring the number of viable cells at 24, 48, and $72 \mathrm{~h}$ after initial seeding. This assay was performed in order to directly investigate the effect of L13a depletion on cell proliferation. The results show that depletion of L13a did not affect rates of cell proliferation (Fig. 4D). Essentially identical results were obtained in L13a-depleted HEK 293T cells, indicating the universality of this finding, independent of cellular background (data not shown).

\section{L13a depletion has no significant effect on ribosomal frameshifting activity}

All of the experiments described above show that L13a is unlikely to have any significant role in the overall function of the ribosome. However, this ribosomal protein may still contribute to the fine-tuning of the ribosome function, e.g., influencing translational fidelity. For example, in bacterial systems, ribosomal proteins L7/L12 (Kirsebom and Isaksson 1985) and S5 (Kirthi et al. 2006) have been found to play important roles in maintaining translation fidelity. In yeast ribosomal proteins L3, L5, and P0 (Peltz et al. 1999; Meskauskas and Dinman 2001; Kinzy et al. 2002) and specific $2^{\prime} \mathrm{OH}$ methylation defects in $25 \mathrm{~S}$ rRNA (BaxterRoshek et al. 2007) have been shown to alter rates of programmed ribosomal frameshifting (PRF). To address this issue, a bicistronic dual luciferase system was used in which the downstream firefly luciferase reporter can only be translated consequent to a programmed -1 ribosomal frameshift ( -1 PRF) directed by sequences derived from either the HIV-1 or SARS-coronaviruses (SARS-CoV) (Dinman et al. 2002; Harger and Dinman 2003; Plant et al. 2005). Depletion of L13a did not significantly affect either HIV-1 or SARS-CoV mediated -1 PRF in U937 cells (Fig. 5).

\section{L13a depletion has a significant effect on the cap-independent mechanism of translation initiation}

Our data have shown that general protein synthesis (cap dependent) is unaffected in L13a-depleted cells. We next hypothesized that L13a depletion and the subsequent defect in rRNA modification might affect the translation of certain mRNAs competent for cap-independent translation. Global defects in another rRNA modification process, pseudouridylation, have been implicated in X-linked dyskeratosis congenita and in defects of the translation initiation promoted by internal ribosome entry sites (IRES) (Yoon et al. 2006). To test the hypothesis that the rRNA 
A
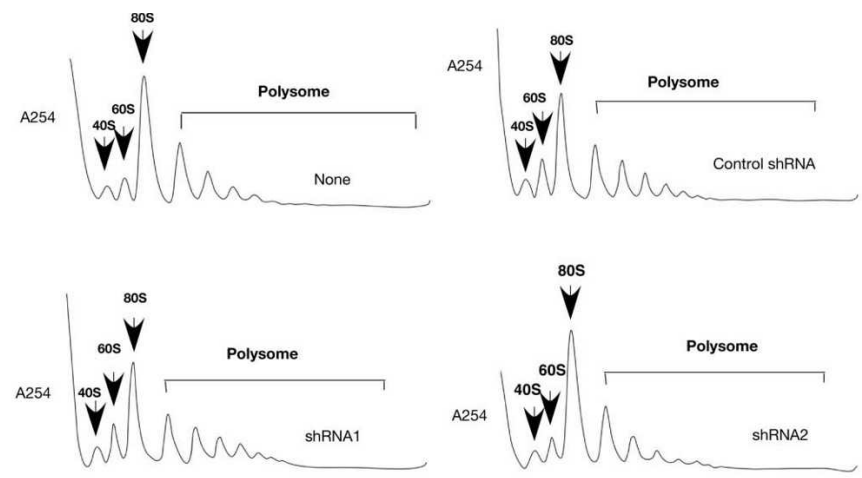

Polysome analysis by UV absorption profile

B
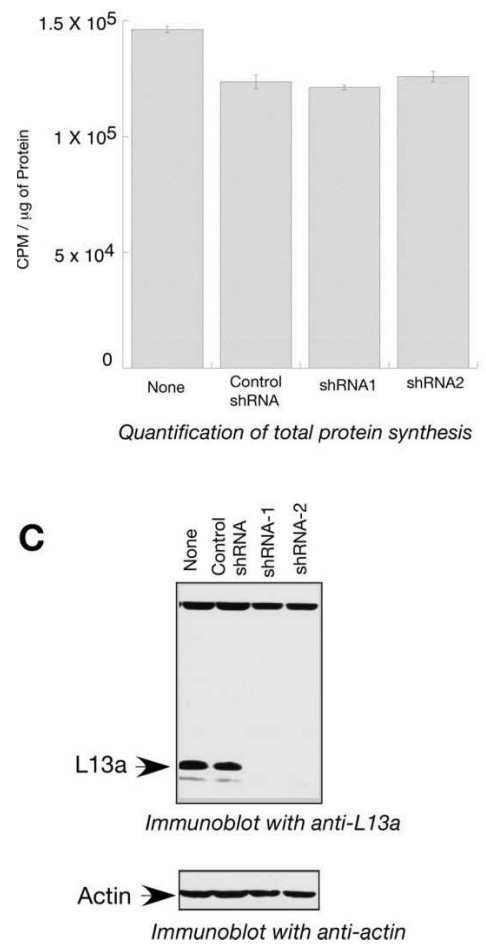

FIGURE 4. Depletion of L13a has no effect on cytoplasmic polysome formation, total protein synthesis, or cell proliferation. (A) Abrogation of L13a by RNA silencing does not alter the ability to form translationally active polysomes. Exponentially growing U937 cells expressing shRNA1, shRNA2, or control shRNA were lysed, and polysomes were resolved by centrifugation through $10 \%-40 \%$ sucrose gradients and $40 \mathrm{~S}, 60 \mathrm{~S}, 80 \mathrm{~S}$, and active polysomes were identified by collecting the fractions through continuous monitoring of $\mathrm{UV}$ absorption. $(B)$ Total protein synthesis remains unaffected upon L13a depletion by RNA silencing. U937 cells expressing shRNA1, shRNA2, or control shRNA were metabolically labeled with Trans $\left[{ }^{35} \mathrm{~S}\right]$ label in methionine-cysteine free medium for $90 \mathrm{~min}$. After the labeling, cells were hydrolyzed by $\mathrm{NaOH}$ followed by tricholoroacetic acid (TCA) precipitation on filter. Filters were washed and counted using a liquid scintillation counter. Protein concentrations of lysates were measured and incorporation of radioactive amino acids into the TCA precipitates were expressed as $\mathrm{CPM} / \mu \mathrm{g}$ of protein. The results of each experiment are the average of triplicate and the error bar was drawn on the basis of three independent experiments. (C) Maintenance of effective L13a depletion. The depletion of L13a was verified by immunoblot analysis with anti-L13a antibody of the $100 \mu \mathrm{g}$ of total cell lysates made from wild-type U937 cells or cells expressing shRNA1, shRNA2, or control shRNA (upper panel). For loading control the same blot was reprobed with anti-actin antibody (lower panel). (D) L13a depletion by RNA silencing has no effect on cell proliferation. Cell proliferation was measured by counting the number of viable cells after $0,24,48$, and $72 \mathrm{~h}$ in culture using an MTT cell proliferation assay kit (ATCC) following the manufacturer's suggested procedure. The results of each experiment are the average of triplicate and the error bar was drawn on the basis of three independent experiments. modification defect engendered by L13a depletion might affect translation of mRNAs competent for cap-independent translation, the activities of several previously characterized cellular and viral IRESes were determined using a well established bicistronic expression system (Pelletier and Sonenberg 1989). In this assay the first cistron is translated by a cap-dependent initiation mechanism while the second is under the control of an IRES element (Fig. 6A). IRES-dependent translation of cellular p53 (Ray et al. 2006), p27 (Kullmann et al. 2002; Cho et al. 2005; Yoon et al. 2006), and SNAT2 (Gaccioli et al. 2006) have been documented using this bicistronic assay. The same bicistronic assay was also used to test the cap-independent translation mediated by HCV (Honda et al. 2000) and CrPV (Wilson et al. 2000; Jan and Sarnow 2002; Yoon et al. 2006) IRESes. These reports also rigorously addressed the authenticities of these cellular IRES activities by ruling out the presence of splice sites and cryptic promoters within the IRES elements. Here, the constructs pRF-p53, pRF-p27 (Yoon et al. 2006), and pRF-SNAT2 were used as bicistronic reporter mRNAs to measure the IRES activities of p53, p27, and SNAT2. The bicistronic constructs pRF-HCV (Honda et al. 2000) and pRF-CrPV (Wilson et al. 2000) were used to measure the IRES activities of HCV and CrPV. Construction of pRF-p53 and pRF-SNAT2 are described in Materials and Methods, while pRF-p27 and pRF-CrPV were kindly provided by L. Hengst (MaxPlanck-Institute of Biochemistry) and P. Sarnow (Stanford University). To quantitatively assess IRES-dependent translation in L13a-depleted cells, the bicistronic reporter mRNAs were transfected into wild-type U937 cells and cells stably expressing functional shRNAs of L13a (shRNA1 and shRNA2). The results obtained suggest that translation initiation from the cellular p53, p27, and SNAT2 IRES elements were significantly inhibited upon depletion of L13a (Fig. 6B-D). Interestingly, internal initiation driven by the 

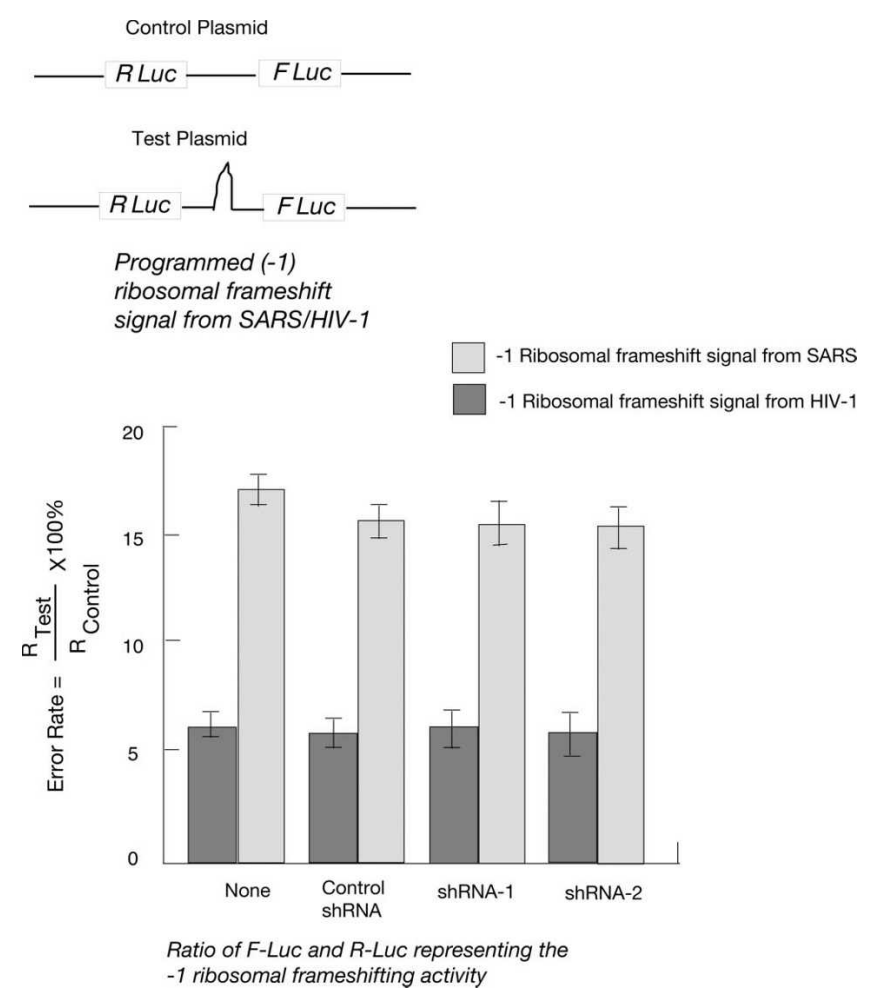

FIGURE 5. Depletion of L13a by RNA silencing does not affect programmed -1 ribosomal frameshifting. (Top panel) Schematic of control and test bicistronic reporter plasmids. (Bottom panel) U937 cells expressing shRNA1, shRNA2, or control shRNA were transfected with bicistronic vectors harboring -1 ribosomal frameshift signals from either SARS-CoV or HIV-1 inserted between the Renilla and Firefly luciferase genes (R Luc and F Luc). A bicistronic vector lacking frameshift signals was used as the readthrough control. Rates of programmed -1 ribosomal frameshifting was expressed by dividing the ratio of F Luc and R Luc in the test plasmid by that of the control plasmid as previously described (Harger and Dinman 2003). The results of each experiment are the average of triplicate and the error bar was drawn on the basis of three independent experiments.

IRES elements of CrPV (Pestova et al. 2004; Wilson et al. 2000) and HCV (Pestova et al. 1998; Honda et al. 2000) remained unaffected by the depletion of L13a (Fig. 6E,F). Similar results were obtained using L13a-depleted HEK $293 \mathrm{~T}$ cells (data not shown). However, these experiments did not address the possibility that the inhibition of the cellular IRES activities might not result from L13a depletion per se, but can be a consequence of the decreased rRNA methylation (Fig. 3). To address this possibility we have further measured the IRES activities in normal cells in the presence of cycloleucine, a chemical inhibitor of rRNA methylation (Caboche and Bachellerie 1977; Scolnik and Eliceiri 1979; O’Connor and Yutzey 1988; Afman et al. 2005). Treatment of the cells with cycloleucine did not change the level of L13a (Fig. 7A); however, as expected, it resulted in abrogation of rRNA methylation (Fig. 7B). We further found that the activities of three cellular IRESes (p53, p27, and SNAT2), but not the two viral IRESes (HCV and CrPV) (Fig. 7C) were decreased under the conditions of cycloleucine treatment. This observation is similar to what we have observed in L13a-depleted cells (Fig. 6). Together, these results suggest that the inhibition of IRESmediated translation seen in L13a-depleted cells is not due to the L13a depletion per se but very likely due to the inhibition of rRNA methylation.

\section{DISCUSSION}

The ability of L13a to silence translation of specific mRNAs was previously discovered using in vitro translation experiments with rabbit reticulocyte lysates (RRL) and inhibition by recombinant phospho-L13a (Mazumder et al. 2003; Kapasi et al. 2007). The question, however, remained whether L13a had any role in mRNA-specific translational silencing in intact cells. The experiments presented in the current study used RNA interference mediated knockdown of L13a in U937 and show the requirement of L13a in translational silencing. Extracellular stimulus-dependent release of L13a from $60 \mathrm{~S}$ ribosomes and its subsequent role in mRNA specific translational silencing provides compelling evidence for an extraribosomal function of this protein (Mazumder et al. 2003). This is also supported by metabolic labeling experiments showing that global protein synthesis is unaffected by L13a depletion of ribosome after $24 \mathrm{~h}$ of IFN- $\gamma$ treatment (Mazumder and Fox 1999). Together these observations suggest that L13a does not play an important role in any fundamental ribosomal functions. The finding in the current study, that knockdown of L13a does not alter overall protein synthesis, is consistent with this view.

Peptidyltransfer, the central catalytic activity of the ribosome, is conducted by rRNA (Ban et al. 2000; Moore and Steitz 2003; Beringer and Rodnina 2007). However, there is accumulating evidence suggesting that an interplay between ribosomal proteins and rRNA is essential for optimal ribosome function (Wilson and Nierhaus 2005). For example, studies in yeast show that disruption of ribosomal protein L30 exhibit only 30\% slower growth rate without affecting $60 \mathrm{~S}$ ribosome assembly but leads to the formation of the stalled translation initiation complex (Baronas-Lowell and Warner 1990). At the same time, disruption of L41 was shown to have no significant effect on yeast growth rates (Yu and Warner 2001). In contrast, L11 (Moritz et al. 1990, 1991), L10 (Hedges et al. 2005), and S14 (Jakovljevic et al. 2004) are essential for 60S and $40 \mathrm{~S}$ ribosome biogenesis. Depletion of L24 (Dresios et al. 2000), L37a (Dresios et al. 2002), and L41 (Dresios et al. 2003) was found to influence the kinetics of peptidyltransferase activity, while L3 and L5 (Meskauskas and Dinman 2001; Meskauskas et al. 2005) have critical roles in maintaining translational reading frame. More recently, studies of L3 in Saccharomyces cerevisiae show that an extended loop of the protein that intrudes deep into the rRNA core plays an indispensable role in both peptidyltransferase 
A

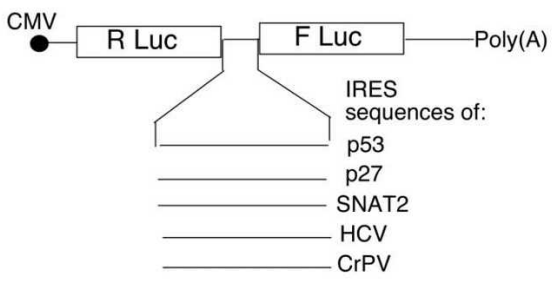

Design of bicistronic constructs with the IRES elements

B

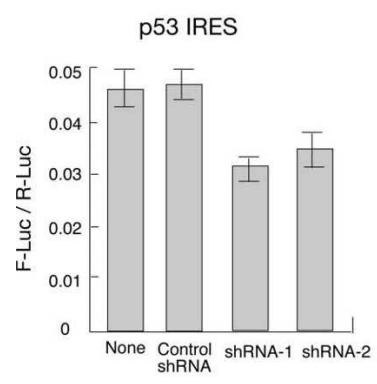

C

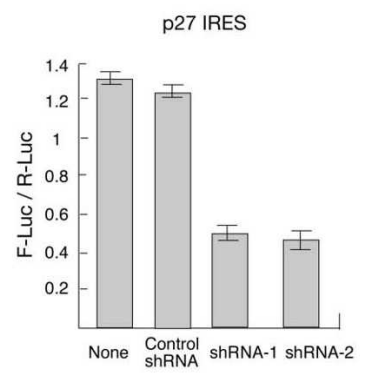

D
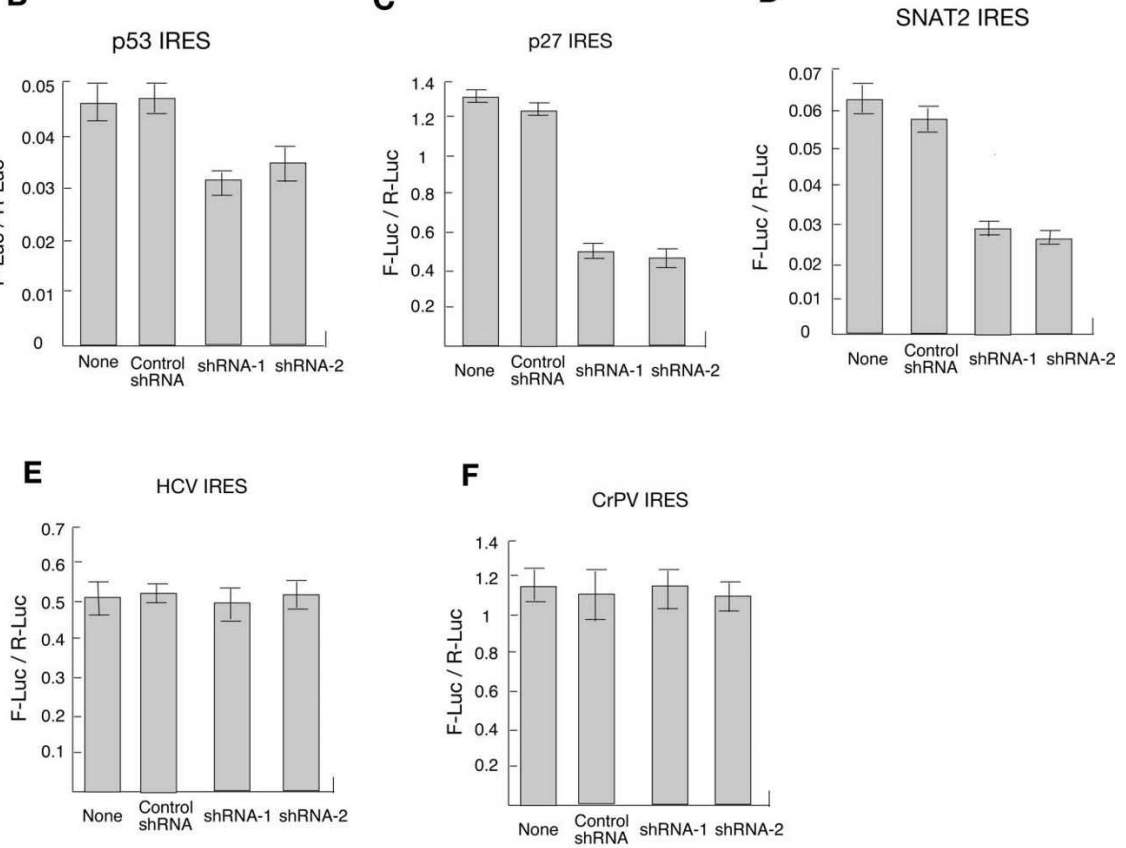

Ratio of F-Luc and R-Luc representing the IRES activity

FIGURE 6. Depletion of L13a inhibits IRES activity. (A) Design of the bicistronic constructs harboring the IRES elements from p53, p27, and SNAT2 between R Luc and F Luc. $(B-F)$ Bicistronic reporters were transfected into the U937 cells expressing shRNA1, shRNA2, or control shRNA by using an Amaxa nucleofection kit (Amaxa). The IRES activities of p53 (B), p27 $(C)$, SNAT2 $(D), \mathrm{HCV}(E)$, and $\mathrm{CrPV}(F)$ were measured by measuring the ratio of F Luc and R Luc by using a Dual Luciferase Assay (DLR) kit from Promega following the manufacturer's suggested procedure. The results of each experiment are the average of triplicate and the error bar was drawn on the basis of three independent experiments.

activity and coordination of elongation factor binding (Meskauskas and Dinman 2007). Similarly, studies in prokaryotes show that ribosomal protein L27 protrudes onto the interface of the $50 \mathrm{~S}$ subunit, thereby reaching the peptidyltransferase active site and contributing to its function (Maguire et al. 2005). In contrast, the finding that depletion of L13a from mammalian ribosomes does not cause defects in cell growth, global rates of protein synthesis, ribosome biogenesis, or translational fidelity argues strongly in favor of the view that this protein is dispensable for general ribosome function.
Comparison of the roles of L13a in metazoan cells and its homologs in lower eukaryotes may illuminate an evolutionary change in the function of this protein. For example, in contrast to the current demonstration that L13a is dispensable in mammalian cells, inactivation of the two yeast L13a homologs rp22 and rp23 (later renamed RPL16A and RPL16B; Planta and Mager 1998) resulted in severe growth retardation and cell death (Chen and Ioannou 1999). This was further supported by systematic deletion studies showing synthetic lethality in the double mutant and revealing that deletion of either of the two isogenes results in slow growth (Tong et al. 2001; Steinmetz et al. 2002). Although the reason for this difference between the lower and higher eukaryotes is not clear, it is possible that the role of L13a may have evolved from originally being essential for ribosomal function to having a new extraribosomal function in metazoans.

X-ray crystallographic studies show that ribosomal L13, the prokaryotic homolog of mammalian L13a, is located entirely on the surface of the ribosome with minimal contact with RNA (Ban et al. 2000). This observation provides a rationale for the observed release and extraribosomal function of L13a (Mazumder et al. 2003). A striking correlation between the extraribosomal functions and surface location can be appreciated through a closer look at other ribosomal proteins as well (Ray et al. 2007). For example, X-ray crystallographic studies show that L5 and L14 make minimal contacts with rRNA and are entirely located on the solventexposed surface of the prokaryotic $50 \mathrm{~S}$ ribosomal subunit (Ban et al. 2000). In eukaryotes, the homologs of these proteins (L11 and L23) have been shown to regulate the p53 activation pathway in a ribosome-independent manner (Lohrum et al. 2003; Bhat et al. 2004; Dai et al. 2004, 2006; Jin et al. 2004).

The current study shows that depletion of L13a in mammalian cells causes significant defect in the methylation of rRNA. Studies in yeast provide evidence that fibrillarin-associated snoRNAs can function as guide RNAs in the site-specific ribose methylation of pre-rRNA (Kiss-Laszlo et al. 1996), and purified C/D snoRNPs from S. cerevisiae was shown to catalyze site-specific 


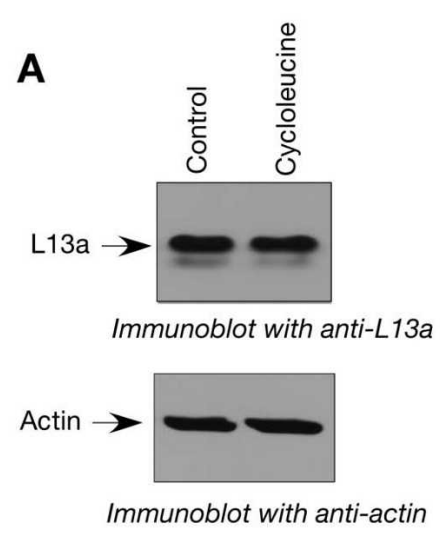

C
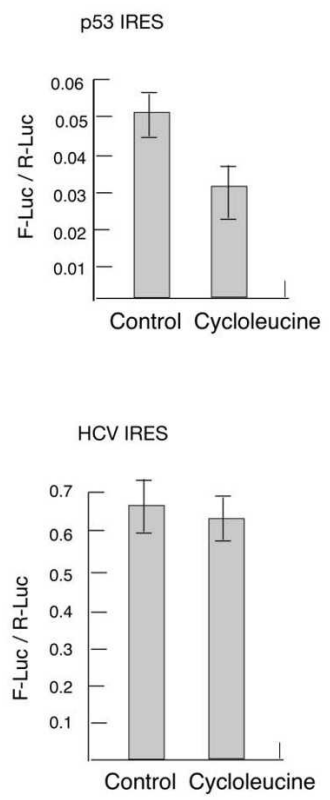

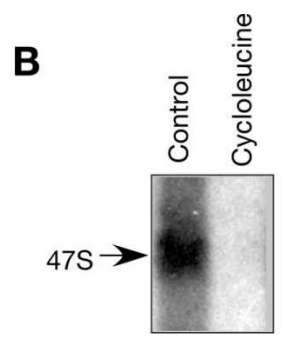

Pulse labeling with

${ }^{3} \mathrm{H}$-methyl methionine

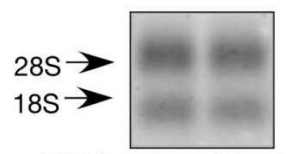

Ethidium bromide staining
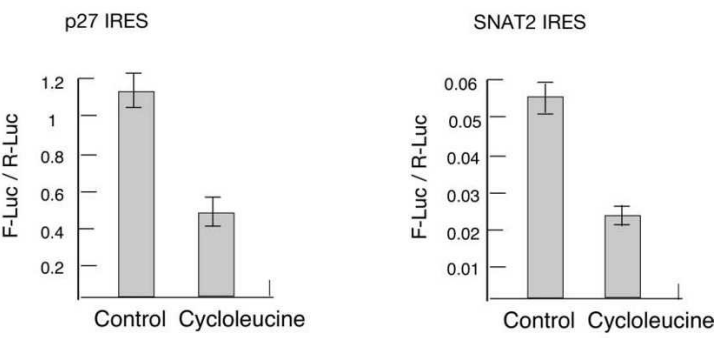

\section{Ratio of F-Luc and R-Luc representing the different IRES activity}

FIGURE 7. Inhibition of rRNA methylation inhibits IRES activity. (A) The methylation inhibitor cycloleucine does not inhibit the cellular level of L13a. U937 cells were treated or not treated with cycloleucine $(2 \mathrm{mg} / \mathrm{mL})$ for $8 \mathrm{~h}$. At the end of cycloleucine treatment total cell lysate was made and was subjected to immunoblot analysis with anti-L13a antibody (upper panel). To check equal loading the same blot was reprobed with anti-actin antibody (lower panel). (B) Cycloleucine inhibits de novo methylation of 47S rRNA. U937 cells were pretreated with cycloleucine $(2 \mathrm{mg} / \mathrm{mL})$ for $7 \mathrm{~h}$ followed by pulse labeling with [methyl- ${ }^{3} \mathrm{H}$ ]-methionine for $1 \mathrm{~h}$. At the end of labeling the total RNA was extracted, resolved in 1\% denaturing agarose gel, transferred to nylon membrane, and subjected to autoradiography. The band of de novo methylated RNA was observed in control cells but not in cycloleucine-treated cells (upper panel). To check the equal loading of RNA, the $28 \mathrm{~S}$ and $18 \mathrm{~S}$ bands were shown on the membrane after transfer (lower panel). (C) Cycloleucine inhibits p53, p27, and SNAT2 IRESes but not the HCV or CrPV IRES. U937 cells were treated with cycloleucine $(2 \mathrm{mg} / \mathrm{mL})$ for $7 \mathrm{~h}$ followed by transfection with the bicistronic reporter by using an Amaxa nucleofection kit (Amaxa). The IRES activities of p53, p27, SNAT2, HCV, and CrPV were measured by measuring the ratio of Firefly luciferase and Renilla luciferase activities using a Dual Luciferase Assay (DLR) kit from Promega following the manufacturer's suggested procedure. The results of each experiment are the average of triplicate and the error bar was drawn on the basis of three independent experiments.

2'-O-methylation of target RNA in vitro (Galardi et al. 2002). Information about the mechanism of rRNA methylation of mammalian ribosomes is limited. It is possible that the mechanisms of rRNA methylation are conserved and that L13a has an important role in snoRNP-mediated methylation as well. On the other hand, the requirement of L13a for methylation of ribosomal RNA may have evolved gradually during evolution from lower to higher eukaryotes. Future experiments will aim to directly address these issues.

The finding that the rRNA modification deficiency in L13a-depleted cells did not promote gross defects in ribosome biogenesis or overall protein synthesis is not unprecedented. In yeast, methylation of nucleolar prerRNA is not essential for pre-rRNA processing (Tollervey et al. 1993). In mice, although DKC1 inactivation promoted reduced rRNA pseudouridylation (Mochizuki et al. 2004; Meier 2005), embryonic DKC1-/ - fibroblasts did not display general protein synthesis defects (Yoon et al. 2006). Together, these studies and our results presented here suggest that defective rRNA modification does not grossly impair general protein synthesis. However, the status of rRNA modification may affect translation of specific mRNAs, resulting in subtle effects, which may not be readily evident by monitoring general protein synthesis. In support of this, the current study shows that cap-independent translation of specific mRNAs may rely on the presence of L13a. The observation that efficient translation from IRES elements derived from cellular mRNAs (i.e., from $\mathrm{p} 27, \mathrm{p} 53$, and SNAT2) requires L13a, but the translation from the viral IRESes is L13a independent also provides significant new insight into the regulation of cellular IRES activity. Although the number of IRES tested here is relatively small, it is nonetheless clear that rRNA methylation is able to discriminate between different IRES elements. Currently, besides the generally structured nature of the RNA, the consensus structural or functional features of IRES remain 
largely undefined. It is tempting to speculate that the methylation status of the rRNA may be regulated by various physiological processes and that the viruses have evolved to encode a more constitutive IRES that is unaffected by such regulatory variations. Our results demonstrate the existence of functional subclasses of IRES, an in-depth dissection of which may allow a better understanding of IRES-ribosome interaction and define the molecular features of the IRES itself. In addition, our studies also demonstrate that the impairment of cellular IRES activities observed in L13a-depleted cells is not due to the L13a depletion per se but due to the consequential inhibition of rRNA methylation.

What are the specific changes in undermethylated ribosomes and why are only specific IRESes inhibited? These questions are the subjects of our ongoing and future experiments.

\section{MATERIALS AND METHODS}

\section{Cells and culture conditions}

Human monocytic U937 cells were maintained in RPMI1640 and HEK 293T cells were maintained in DMEM supplemented with $10 \%$ heat inactivated fetal bovine serum (FBS), $2 \mathrm{mM}$ glutamine, and $100 \mathrm{U} / \mathrm{mL}$ of penicillin and streptomycin at $37^{\circ} \mathrm{C}$ and $5 \% \mathrm{CO}_{2}$.

\section{Construction of lentiviral vector for transduction of shRNA sequences against L13a}

Nucleotide positions $460-478$ and $147-169$ of the ORF of L13a were selected as a 19-nt target sequence following previously published guidelines (Elbashir et al. 2001; Musiyenko et al. 2007). The target shRNA sequences (shRNA1 and shRNA2) were included in sense and antisense oligonucleotides encoding the shRNAs that can serve as a precursor for the siRNAs following published guidelines (Brummelkamp et al. 2002). A scrambled shRNA sequence was used as a control. Synthetic sense and antisense oligonucleotides encoding the shRNAs (Fig. 1A) were annealed and ligated into the SalI and EcoRI sites of lentiviral vector pLU6EGFP (Fig. 1B) downstream of RNA polymerase IIIspecific U6 promoter. The vector pLU6EGFP (a gift from Dr. Ratan Maitra, Cleveland Biolabs, Inc.) was made by subcloning the U6 promoter into the ClaI site of the vector LRV-EGFP (Malur et al. 2005). A scrambled shRNA sequence was used to generate control shRNA. The resulting plasmid pLU6EGFP-shL13a was used to generate the recombinant lentivirus.

\section{Preparation of the packaged lentivirus particle containing the shRNA sequences against L13a}

A previously published method (Lee et al. 2004) was followed to make the packaged lentivirus particle with the shRNA sequences. HEK 293T cells $\left(2 \times 10^{6}\right)$ were plated on $100 \mathrm{~mm}$ tissue culture plates. After $16 \mathrm{~h}$, cells were transfected with $20 \mu \mathrm{g}$ of transducing vector pLU6EGFP-shL13a and vectors encoding the packaging components HIV gagpol $(10 \mu \mathrm{g})$, HIV rev $(8 \mu \mathrm{g})$, and VSVG $(6$ $\mu \mathrm{g}$ ) in the presence of LipofectAMINE 2000 (Invitrogen). The medium was changed the next day and cells were cultured for another $48 \mathrm{~h}$, after which GFP expression was monitored. Conditioned medium was then collected and cleared of debris by low speed centrifugation $(2500 \mathrm{~g}$ for $5 \mathrm{~min}$ ), passed through $0.45-\mu \mathrm{m}$ filters, and stored at $-70^{\circ} \mathrm{C}$. The collection process was repeated one more time after $48 \mathrm{~h}$, and conditioned medium from the two collections was pooled and ultracentrifuged at $100,000 \mathrm{~g}$ at $4^{\circ} \mathrm{C}$ for $2.5 \mathrm{~h}$. Pelleted viral particles were suspended in $1 \times$ sterile $\mathrm{PBS}$ and stored in aliquots at $-70^{\circ} \mathrm{C}$. The viral stocks were assayed for the p24 core antigen using HIV-1 Antigen ELISA kit according to manufacturer's instructions (BioMerieux, Inc.).

\section{Transduction of cells with recombinant lentivirus and isolation of shRNA expressing cells}

U937 and HEK $293 \mathrm{~T}$ cells $\left(1 \times 10^{6}\right)$ were seeded into 24 well plates in $0.5 \mathrm{~mL}$ of complete medium (RPMI for U937 cells and DMEM for HEK 293T cells) and transduced by recombinant lentivirus at a M.O.I of 10:1. Transduction was carried out in the presence of polybrene $(10 \mu \mathrm{g} / \mathrm{mL})$ and IL-2 and IL-3 $(100 \mathrm{ng} / \mathrm{mL})$. After $24 \mathrm{~h}$, transduced cells were transferred to $175 \mathrm{~mm}$ flasks in selection medium with $10 \mu \mathrm{g} / \mathrm{mL}$ of blasticidin. After $48 \mathrm{~h}$ in selection medium, cells were counted and seeded into 96 well plates in a ratio of 1 cell per well and were monitored for GFP expression. After $15 \mathrm{~d}$ in selection media, GFP positive cells were transferred to $25 \mathrm{~mm}$ flasks and tested for silencing of L13a expression by immunoblot analysis with anti-L13a.

\section{Metabolic labeling of cells and monitoring of specific and general protein synthesis}

To monitor the de novo protein synthesis of Cp, U937 cells expressing shRNA1, shRNA2, or control shRNA $\left(8 \times 10^{6}\right.$ cells in $4 \mathrm{~mL}$ of RPMI 1640 medium) were treated with IFN- $\gamma(500 \mathrm{U} / \mathrm{mL})$ for up to $24 \mathrm{~h}$. Cells were collected by centrifugation and metabolically labeled by incubation for $2 \mathrm{~h}$ with $\left[{ }^{35} \mathrm{~S}\right]$ methionine $(100 \mathrm{mCi} / \mathrm{mL}$; Trans-Label, ICN) in methionine-free medium. Cells were collected by centrifugation, lysed in $50 \mathrm{mM}$ Tris $(\mathrm{pH}$ 7.6), $50 \mathrm{mM} \mathrm{NaCl}, 1 \mathrm{mM}$ PMSF, $1 \mathrm{mM}$ DTT, and 0.5\% NP40, and newly synthesized ${ }^{35} \mathrm{~S}$-labeled $\mathrm{Cp}$ was immunoprecipated using anti-Cp antibody (Accurate Chemical). Proteins were resolved by 7\% SDS-PAGE, gel was fixed, treated with Amplify (Amersham), dried, and exposed to MR film (Kodak).

To measure total protein synthesis, U937 cells were incubated in methionine-cysteine-free RPMI1640 medium for $30 \mathrm{~min}$ in 24 well plates $\left(10^{6}\right.$ cells per well) before labeling. In vivo metabolic labeling was performed by adding Trans $\left[{ }^{35} \mathrm{~S}\right]$ label (MP Biomedicals) at a final concentration of $100 \mu \mathrm{Ci} / \mathrm{mL}$ containing labeled Lmethionine and L-cysteine. After $90 \mathrm{~min}$, the cells were washed with ice-cold PBS and incubated with 1:1 $1 \times \mathrm{PBS}$ and $1 \mathrm{M} \mathrm{NaOH}$ for $10-15 \mathrm{~min}$ at $37^{\circ} \mathrm{C}$ to stop the labeling. Ice-cold TCA was then added to the aliquots of cell lysates to a final concentration of $10 \%$, mixed well, placed on ice for $1 \mathrm{~h}$, and filtered through GF/C filter discs (Millipore). The GF/C discs were washed three times with $5 \%$ TCA and once with $10 \mathrm{~mL}$ of EtOH (ice cold). Air-dried filter discs were placed in scintillation vials with scintillation fluid and counted using a liquid scintillation counter. Total protein content was measured using the Bradford assay to determine the counts per minute per microgram of protein. 


\section{Metabolic labeling of cells to examine rRNA processing and methylation}

To examine the rRNA processing, $1 \times 10^{6}$ U937 cells expressing either shRNA1, shRNA2, or control shRNA were incubated in $1 \mathrm{~mL}$ of $0.5 \%$ serum containing RPMI medium in the presence of $50 \mu \mathrm{Ci}$ of $\left[{ }^{3} \mathrm{H}\right]$-uridine for $1 \mathrm{~h}$. At the end of incubation the cells were chased with nonradioactive medium for 0,45 , or $90 \mathrm{~min}$. RNAs were extracted at the end of the indicated chase periods, resolved through a $1 \%$ agarose gel, and transferred to Hybond $\mathrm{N}+$ membrane (Amersham). Dried membranes were treated with Amplify (Amersham) and exposed to MS film (Kodak). Turnover rates of the $47 \mathrm{~S}$ precursor rRNA to the processed and matured $28 \mathrm{~S}$ and $18 \mathrm{~S}$ rRNA were determined. To examine rRNA methylation, $1 \times 10^{6}$ U937 cells expressing either shRNA1, shRNA2, or control shRNA were preincubated in $1 \mathrm{~mL}$ of methionine-free RPMI medium for $30 \mathrm{~min}$ followed by pulse labeling with $50 \mu \mathrm{Ci}$ of [methyl- $\left.{ }^{3} \mathrm{H}\right]$-methionine (Amersham) for $1 \mathrm{~h}$. At the end of the pulse period, cells were washed and total RNAs were extracted and analyzed as above. To monitor total RNA synthesis in parallel, the same number of cells were pulse labeled with $50 \mu \mathrm{Ci}$ of $\left[{ }^{3} \mathrm{H}\right]-$ uridine for $1 \mathrm{~h}$ followed by extraction of total RNA. The RNAs were processed as above.

\section{Cell proliferation assays}

Cell proliferation was measured using the MTT cell proliferation assay kit (ATCC). Cells were seeded at $2 \times 10^{4}$ cells per well in 96-well plates and incubated at $37^{\circ} \mathrm{C}$ for $0,24,48$, and $72 \mathrm{~h}$, respectively. Absorbance was determined at $570 \mathrm{~nm}$ with background subtraction at $650 \mathrm{~nm}$. This assay relies on the reduction of yellow tetrazolium MTT [3-(4,5-dimethylthiazolyl-2)-2,5diphenyltetrazolium bromide] by metabolically active cells to purple colored formazan followed by spectrophotometric quatification. The number of cells was calculated from a standard curve of cell number versus absorbance.

\section{Analysis of polysomes and $90 \mathrm{~S}$ pre-ribosomes}

Polysomes were analyzed from cytoplasmic extracts and 90S preribosomes were analyzed from nuclear extracts. For preparation of cytoplasmic extracts, cells from three $175 \mathrm{~cm}^{2}$ tissue culture plates (60\% confluence) were treated with $100 \mu \mathrm{g} / \mathrm{mL}$ cycloheximide (MP Biomedicals) for $15 \mathrm{~min}$ at $37^{\circ} \mathrm{C}$, harvested, and washed with ice-cold phosphate-buffered saline containing cycloheximide (100 $\mu \mathrm{g} / \mathrm{mL}$ ). Cells were pelleted by centrifugation, lysed in $375 \mu \mathrm{L}$ of lysis buffer containing Polysome Buffer (PB; $10 \mathrm{mM}$ HEPES at $\mathrm{pH} 7.5,100 \mathrm{mM} \mathrm{KCl}, 2.5 \mathrm{mM} \mathrm{MgCl}_{2}, 1 \mathrm{mM}$ dithiothreitol [DTT], $50 \mathrm{U}$ recombinant RNasin [Promega], and 0.1\% Igepal-CA630 [Sigma]) followed by two cycles of rapid freeze-thawing. Nuclei were pelleted by centrifugation in a microcentrifuge at 13,000 rpm for $5 \mathrm{~min}$ at $40^{\circ} \mathrm{C}$. Supernatants (cytoplasmic extracts) were transferred to new $1.5 \mathrm{~mL}$ tubes on ice. Five O.D. units of cytoplasmic extracts were carefully layered over $10 \%-50 \%$ linear sucrose gradients (in $\mathrm{PB}$ ) and centrifuged at $17,000 \mathrm{rpm}$ in a Beckman SW32.1 Ti rotor for $18 \mathrm{~h}$ at $4^{\circ} \mathrm{C}$. For preparation of nuclear extracts, cells from five $175 \mathrm{~cm}^{2}$ tissue culture plates $(60 \%$ confluency; $\sim 5 \times 10^{7}$ cells) were harvested and washed with icecold phosphate-buffered saline twice, lysed in $1 \mathrm{~mL}$ hypotonic buffer (10 mM HEPES at pH 7.5, $10 \mathrm{mM} \mathrm{KCl}, 10 \mathrm{mM} \mathrm{NaF}, 1 \mathrm{mM}$ PMSF, $0.1 \%$ Igepal-CA 630 ) by vortexing at half maximal speed for $15 \mathrm{sec}$. Nuclei were collected by centrifugation at $1400 \mathrm{~g}$ for 5 min, lysed in nuclei lysis buffer $(50 \mathrm{mM}$ Tris- $\mathrm{HCl}$ at $\mathrm{pH} \mathrm{8,150}$ $\mathrm{mM} \mathrm{NaCl}, 0.5 \%$ Igepal-CA 630, 1 mM PMSF), and kept on ice for $30 \mathrm{~min}$ with occasional vortexing. Nuclear extracts were collected by centrifugation at $15,000 \mathrm{rpm}$ for $15 \mathrm{~min}$ at $4^{\circ} \mathrm{C}$, loaded on top of $10 \%-40 \%$ sucrose gradients (in PB), and centrifuged at 20,000 rpm in a Beckman SW32.1 Ti rotor for $18 \mathrm{~h}$ at $4^{\circ} \mathrm{C}$. Gradients were fractionated using an ISCO Gradient Fractionation System equipped with UA-6 detector. The presence of unprocessed prerRNA intermidiate was confirmed by RT-PCR analysis of the total RNA isolated from the 90S using primers specific for the 5'ETS and $18 \mathrm{~S}$ regions. The sequences of the primers are $5^{\prime} \mathrm{ETS}$ (forward): 5'-GCGCACGTCCCGTGCTC-3'， 5'ETS (reverse): 5'-GAGGGG GAAGCGGAGGAGG-3', 18S (forward): 5'-GCGCTGACCCCC TTCGC-3' ${ }^{\prime}$, and $18 \mathrm{~S}$ (reverse): 5' -CTCCCCGGGTCGGGAGTG-3'.

\section{Construction of bicistronic IRES reporter plasmids}

The IRES sequence of p53 [p53(+39) 5'UTR] was amplified by RT-PCR amplification from U937 cell total RNA using the primers based on published sequence (Ray et al. 2006). The sequence was verified and cloned into pRF vector (Yoon et al. 2006) to generate pRF-p53. To make pRF-SNAT2, the SNAT2 IRES sequence was excised from the construct m/SNAT2-1 (Gaccioli et al. 2006) and subcloned into pRF vector. Plasmids to monitor HIV-1 and SARS-Corona virus directed programmed -1 ribosomal frameshifting were previously described (Dinman et al. 2002; Harger and Dinman 2003; Plant et al. 2005).

\section{Dual luciferase assays}

Dual luciferase assays were performed using the DLR assay kit (Promega). Cells were seeded at $5 \times 10^{5}$ cells per well in 24 -well plates and incubated at $37^{\circ} \mathrm{C}$. After $24 \mathrm{~h}$ HEK293T and U937 cells were transfected with dual luciferase reporter plasmids using the Lipofectamine-2000 (Invitrogen) and Amaxa neucleofection kit (Amaxa) following the manufacturer's suggested procedures. Cell lysates were prepared after an additional $24 \mathrm{~h}$, and reagents for the assay were prepared following the manufacturer's instruction. Luminescence was measured using a 20/20n luminometer (Turner BioSystems). Ratios of firefly and Renilla luciferase derived luminescence were recorded, and efficiencies of either programmed ribosomal frameshifting or IRES-mediated initiation were determined as previously described (Pelletier and Sonenberg 1989; Harger and Dinman 2003).

\section{ACKNOWLEDGMENTS}

This work was supported by PHS grants HL79164 (to B.M.), GM058859 (to J.D.D.), and AI059267 (to S.B) from the NIH, and by startup and research challenge funds (to B.M. and A.A.K.) from Cleveland State University. S.C. is supported by a Postdoctoral Fellowship grant from the American Heart Association. We thank Ratan Maitra for generously providing the pLU6EGFP plasmid and valuable suggestions for preparation of recombinant lentivirus; Maria Hatzoglou for the SNAT2 IRES construct and helpful discussions; and Peter Sarnow, Tatyana Pestova, Ludger Hengst, and Davide Ruggero for different IRES constructs.

Received June 19, 2007; accepted August 21, 2007. 


\section{REFERENCES}

Afman, L.A., Blom, H.J., Drittij, M.J., Brouns, M.R., and Van Straaten, H.W.M. 2005. Inhibition of transmethylation disturbs neurulation in chick embryos. Brain Res. Dev. Brain Res. 158: 5965.

Bachellerie, J.P. and Cavaille, J. 1997. Guiding ribose methylation of rRNA. Trends Biochem. Sci. 22: 257-261.

Ban, N., Nissen, P., Hansen, J., Moore, P.B., and Steitz, T.A. 2000. The complete atomic structure of the large ribosomal subunit at 2.4 A resolution. Science 289: 905-920.

Baronas-Lowell, D.M. and Warner, J.R. 1990. Ribosomal protein L30 is dispensable in the yeast Saccharomyces cerevisiae. Mol. Cell. Biol. 10: $5235-5243$.

Baxter-Roshek, J.L., Petrov, A.N., and Dinman, J.D. 2007. Optimization of ribosome structure and function by rRNA base modification. PLoS ONE 2: e174. doi: 10.1371/journal.pone.0000174.

Beringer, M. and Rodnina, M.V. 2007. The ribosomal peptidyl transferase. Mol. Cell 26: 311-321.

Bhat, K.P., Itahana, K., Jin, A., and Zhang, Y. 2004. Essential role of ribosomal protein L11 in mediating growth inhibition-induced p53 activation. EMBO J. 23: 2402-2412.

Brodersen, D.E. and Nissen, P. 2005. The social life of ribosomal proteins. FEBS J. 272: 2098-2108.

Brummelkamp, T.R., Bernards, R., and Agami, R. 2002. A system for stable expression of short interfering RNAs in mammalian cells. Science 296: 550-553.

Caboche, M. and Bachellerie, J.P. 1977. RNA methylation and control of eukaryotic RNA biosynthesis. Effects of cycloleucine, a specific inhibitor of methylation, on ribosomal RNA maturation. Eur. J. Biochem. 74: 19-29.

Cech, T.R. 2000. Structural biology. The ribosome is a ribozyme. Science 289: 878-879.

Chen, F.W. and Ioannou, Y.A. 1999. Ribosomal proteins in cell proliferation and apoptosis. Int. Rev. Immunol. 18: 429448.

Chen, F.W., Davies, J.P., and Ioannou, Y.A. 1998. Differential gene expression in apoptosis: Identification of ribosomal protein 23K, a cell proliferation inhibitor. Mol. Genet. Metab. 64: 271282.

Cho, P.F., Poulin, F., Cho-Park, Y.A., Cho-Park, I.B., Chicoine, J.D., Lasko, P., and Sonenberg, N. 2005. A new paradigm for translational control: Inhibition via $5^{\prime}-3^{\prime}$ mRNA tethering by Bicoid and the eIF4E cognate 4EHP. Cell 121: 411-423.

Dai, M.S., Zeng, S.X., Jin, Y., Sun, X.X., David, L., and Lu, H. 2004. Ribosomal protein L23 activates p53 by inhibiting MDM2 function in response to ribosomal perturbation but not to translation inhibition. Mol. Cell. Biol. 24: 7654-7668.

Dai, M.S., Shi, D., Jin, Y., Sun, X.X., Zhang, Y., Grossman, S.R., and Lu, H. 2006. Regulation of the MDM2-p53 pathway by ribosomal protein L11 involves a post-ubiquitination mechanism. J. Biol. Chem. 281: 24304-24313.

Dinman, J.D., Richter, S., Plant, E.P., Taylor, R.C., Hammell, A.B., and Rana, T.M. 2002. The frameshift signal of HIV-1 involves a potential intramolecular triplex RNA structure. Proc. Natl. Acad. Sci. 99: 5331-5336.

Dresios, J., Derkatch, I.L., Liebman, S.W., and Synetos, D. 2000. Yeast ribosomal protein L24 affects the kinetics of protein synthesis and ribosomal protein L39 improves translational accuracy, while mutants lacking both remain viable. Biochemistry 39: 7236-7244.

Dresios, J., Chan, Y.L., and Wool, I.G. 2002. The role of the zinc finger motif and of the residues at the amino terminus in the function of yeast ribosomal protein YL37a. J. Mol. Biol. 316: 475-488.

Dresios, J., Panopoulos, P., Suzuki, K., and Synetos, D. 2003. A dispensable yeast ribosomal protein optimizes peptidyltransferase activity and affects translocation. J. Biol. Chem. 278: 33143322 .
Elbashir, S.M., Harborth, J., Lendeckel, W., Yalcin, A., Weber, K., and Tuschl, T. 2001. Duplexes of 21-nucleotide RNAs mediate RNA interference in cultured mammalian cells. Nature 411: 494-498.

Fromont-Racine, M., Senger, B., Saveanu, C., and Fasiolo, F. 2003. Ribosome assembly in eukaryotes. Gene 313: 17-42.

Gaccioli, F., Huang, C.C., Wang, C., Bevilacqua, E., FranchiGazzola, R., Gazzola, G.C., Bussolati, O., Snider, M.D., and Hatzoglou, M. 2006. Amino acid starvation induces the SNAT2 neutral amino acid transporter by a mechanism that involves eukaryotic initiation factor $2 \alpha$ phosphorylation and cap-independent translation. J. Biol. Chem. 281: 17929-17940.

Galardi, S., Fatica, A., Bachi, A., Scaloni, A., Presutti, C., and Bozzoni, I. 2002. Purified box C/D snoRNPs are able to reproduce site-specific 2'-O-methylation of target RNA in vitro. Mol. Cell. Biol. 22: 6663-6668.

Harger, J.W. and Dinman, J.D. 2003. An in vivo dual-luciferase assay system for studying translational recoding in the yeast Saccharomyces cerevisiae. RNA 9: 1019-1024.

Harnpicharnchai, P., Jakovljevic, J., Horsey, E., Miles, T., Roman, J., Rout, M., Meagher, D., Imai, B., Guo, Y., Brame, C.J., et al. 2001. Composition and functional characterization of yeast $66 \mathrm{~S}$ ribosome assembly intermediates. Mol. Cell 8: 505-515.

Hedges, J., West, M., and Johnson, A.W. 2005. Release of the export adapter, Nmd3p, from the $60 \mathrm{~S}$ ribosomal subunit requires Rpl10p and the cytoplasmic GTPase Lsglp. EMBO J. 24: 567579.

Honda, M., Kaneko, S., Matsushita, E., Kobayashi, K., Abell, G.A., and Lemon, S.M. 2000. Cell cycle regulation of hepatitis C virus internal ribosomal entry site-directed translation. Gastroenterology 118: $152-162$.

Jakovljevic, J., de Mayolo, P.A., Miles, T.D., Nguyen, T.M., LegerSilvestre, I., Gas, N., and Woolford Jr., J.L. 2004. The carboxyterminal extension of yeast ribosomal protein S14 is necessary for maturation of $43 \mathrm{~S}$ preribosomes. Mol. Cell 14: 331-342.

Jan, E. and Sarnow, P. 2002. Factorless ribosome assembly on the internal ribosome entry site of cricket paralysis virus. J. Mol. Biol. 324: 889-902.

Jin, A., Itahana, K., O'Keefe, K., and Zhang, Y. 2004. Inhibition of HDM2 and activation of p53 by ribosomal protein L23. Mol. Cell. Biol. 24: 7669-7680.

Kapasi, P., Chaudhuri, S., Vyas, K., Baus, D., Komar, A.A., Fox, P.L., Merrick, W.C., and Mazumder, B. 2007. L13a blocks 48S assembly: Role of a general initiation factor in mRNA-specific translational control. Mol. Cell 25: 113-126.

Kinzy, T.G., Harger, J.W., Carr-Schmid, A., Kwon, J., Shastry, M., Justice, M.C., and Dinman, J.D. 2002. New targets for antivirals: The ribosomal A-site and the factors that interact with it. Virology 300: $60-70$.

Kirsebom, L.A. and Isaksson, L.A. 1985. Involvement of ribosomal protein L7/L12 in control of translational accuracy. Proc. Natl. Acad. Sci. 82: 717-721.

Kirthi, N., Roy-Chaudhuri, B., Kelley, T., and Culver, G.M. 2006. A novel single amino acid change in small subunit ribosomal protein S5 has profound effects on translational fidelity. RNA 12: 20802091.

Kiss-Laszlo, Z., Henry, Y., Bachellerie, J.P., Caizergues-Ferrer, M., and Kiss, T. 1996. Site-specific ribose methylation of preribosomal RNA: A novel function for small nucleolar RNAs. Cell 85: 10771088.

Kobayashi, T., Sasaki, Y., Oshima, Y., Yamamoto, H., Mita, H., Suzuki, H., Toyota, M., Tokino, T., Itoh, F., Imai, K., et al. 2006. Activation of the ribosomal protein L13 gene in human gastrointestinal cancer. Int. J. Mol. Med. 18: 161-170.

Kressler, D., Linder, P., and de La Cruz, J. 1999. Protein trans-acting factors involved in ribosome biogenesis in Saccharomyces cerevisiae. Mol. Cell. Biol. 19: 7897-7912.

Kullmann, M., Gopfert, U., Siewe, B., and Hengst, L. 2002. ELAV/Hu proteins inhibit p27 translation via an IRES element in the p27 5'UTR. Genes \& Dev. 16: 3087-3099. 
Lee, J.S., Hmama, Z., Mui, A., and Reiner, N.E. 2004. Stable gene silencing in human monocytic cell lines using lentiviraldelivered small interference RNA. Silencing of the p110 $\alpha$ isoform of phosphoinositide 3-kinase reveals differential regulation of adherence induced by $1 \alpha, 25$-dihydroxycholecalciferol and bacterial lipopolysaccharide. J. Biol. Chem. 279: 93799388.

Lewis, J.D. and Tollervey, D. 2000. Like attracts like: Getting RNA processing together in the nucleus. Science 288: 1385-1389.

Lohrum, M.A., Ludwig, R.L., Kubbutat, M.H., Hanlon, M., and Vousden, K.H. 2003. Regulation of HDM2 activity by the ribosomal protein L11. Cancer Cell 3: 577-587.

Maguire, B.A., Beniaminov, A.D., Ramu, H., Mankin, A.S., and Zimmermann, R.A. 2005. A protein component at the heart of an RNA machine: The importance of protein L27 for the function of the bacterial ribosome. Mol. Cell 20: 427-435.

Malur, A.G., Chattopadhyay, S., Maitra, R.K., and Banerjee, A.K. 2005. Inhibition of STAT 1 phosphorylation by human parainfluenza virus type 3 C protein. J. Virol. 79: 7877-7882.

Mazumder, B. and Fox, P.L. 1999. Delayed translational silencing of ceruloplasmin transcript in $\gamma$ interferon-activated U937 monocytic cells: Role of the $3^{\prime}$ untranslated region. Mol. Cell. Biol. 19: 6898-6905.

Mazumder, B., Sampath, P., Seshadri, V., Maitra, R.K., DiCorleto, P.E., and Fox, P.L. 2003. Regulated release of L13a from the $60 \mathrm{~S}$ ribosomal subunit as a mechanism of transcriptspecific translational control. Cell 115: 187-198.

Meier, U.T. 2005. The many facets of H/ACA ribonucleoproteins. Chromosoma 114: 1-14.

Meskauskas, A. and Dinman, J.D. 2001. Ribosomal protein L5 helps anchor peptidyl-tRNA to the P-site in Saccharomyces cerevisiae. RNA 7: 1084-1096.

Meskauskas, A. and Dinman, J.D. 2007. Ribosomal protein L3: Gatekeeper to the A site. Mol. Cell 25: 877-888.

Meskauskas, A., Petrov, A.N., and Dinman, J.D. 2005. Identification of functionally important amino acids of ribosomal protein L3 by saturation mutagenesis. Mol. Cell. Biol. 25: 10863-10874.

Mochizuki, Y., He, J., Kulkarni, S., Bessler, M., and Mason, P.J. 2004. Mouse dyskerin mutations affect accumulation of telomerase RNA and small nucleolar RNA, telomerase activity, and ribosomal RNA processing. Proc. Natl. Acad. Sci. 101: 10756-10761.

Moore, P.B. and Steitz, T.A. 2003. The structural basis of large ribosomal subunit function. Annu. Rev. Biochem. 72: 813-850.

Moritz, M., Paulovich, A.G., Tsay, Y.F., and Woolford Jr., J.L. 1990. Depletion of yeast ribosomal proteins L16 or rp59 disrupts ribosome assembly. J. Cell Biol. 111: 2261-2274.

Moritz, M., Pulaski, B.A., and Woolford Jr., J.L. 1991. Assembly of $60 \mathrm{~S}$ ribosomal subunits is perturbed in temperature-sensitive yeast mutants defective in ribosomal protein L16. Mol. Cell. Biol. 11: 5681-5692.

Musiyenko, A., Bitko, V., and Barik, S. 2007. RNAi-dependent and -independent antiviral phenotypes of chromosomally integrated shRNA clones: Role of VASP in respiratory syncytial virus growth. J. Mol. Med. 85: 745-752.

Nissen, P., Hansen, J., Ban, N., Moore, P.B., and Steitz, T.A. 2000. The structural basis of ribosome activity in peptide bond synthesis. Science 289: 920-930.

O'Connor, C.M. and Yutzey, K.E. 1988. Enhanced carboxyl methylation of membrane-associated hemoglobin in human erythrocytes. J. Biol. Chem. 263: 1386-1390.

Ogle, J.M., Brodersen, D.E., Clemons Jr., W.M., Tarry, M.J., Carter, A.P., and Ramakrishnan, V. 2001. Recognition of cognate transfer RNA by the 30 S ribosomal subunit. Science 292: 897 902.

Pardee, A.B. 1989. G1 events and regulation of cell proliferation. Science 246: 603-608.

Pelletier, J. and Sonenberg, N. 1989. Internal binding of eucaryotic ribosomes on poliovirus RNA: Translation in HeLa cell extracts. J. Virol. 63: 441-444.
Peltz, S.W., Hammell, A.B., Cui, Y., Yasenchak, J., Puljanowski, L., and Dinman, J.D. 1999. Ribosomal protein L3 mutants alter translational fidelity and promote rapid loss of the yeast killer virus. Mol. Cell. Biol. 19: 384-391.

Pestova, T.V., Shatsky, I.N., Fletcher, S.P., Jackson, R.J., and Hellen, C.U. 1998. A prokaryotic-like mode of cytoplasmic eukaryotic ribosome binding to the initiation codon during internal translation initiation of hepatitis $\mathrm{C}$ and classical swine fever virus RNAs. Genes \& Dev. 12: 67-83.

Pestova, T.V., Lomakin, I.B., and Hellen, C.U. 2004. Position of the CrPV IRES on the 40S subunit and factor dependence of IRES/80S ribosome assembly. EMBO Rep. 5: 906-913.

Plant, E.P., Perez-Alvarado, G.C., Jacobs, J.L., Mukhopadhyay, B., Hennig, M., and Dinman, J.D. 2005. A three-stemmed mRNA pseudoknot in the SARS coronavirus frameshift signal. PLoS Biol. 3: e172. doi: 10.1371/journal.pbio.0030172.

Planta, R.J. and Mager, W.H. 1998. The list of cytoplasmic ribosomal proteins of Saccharomyces cerevisiae. Yeast 14: 471-477.

Ray, P.S., Grover, R., and Das, S. 2006. Two internal ribosome entry sites mediate the translation of p53 isoforms. EMBO Rep. 7: 404410.

Ray, P.S., Arif, A., and Fox, P.L. 2007. Macromolecular complexes as depots for releasable regulatory proteins. Trends Biochem. Sci. 32: $158-164$.

Ruggero, D. and Pandolfi, P.P. 2003. Does the ribosome translate cancer? Nat. Rev. Cancer 3: 179-192.

Sampath, P., Mazumder, B., Seshadri, V., Gerber, C.A., Chavatte, L., Kinter, M., Ting, S.M., Dignam, J.D., Kim, S., Driscoll, D.M., et al. 2004. Noncanonical function of glutamyl-prolyl-tRNA synthetase: Gene-specific silencing of translation. Cell 119: 195-208.

Scolnik, P.A. and Eliceiri, G.L. 1979. Methylation sites in Hela cell ribosomal proteins. Eur. J. Biochem. 101: 93-101.

Sharma, M.R., Koc, E.C., Datta, P.P., Booth, T.M., Spremulli, L.L., and Agrawal, R.K. 2003. Structure of the mammalian mitochondrial ribosome reveals an expanded functional role for its component proteins. Cell 115: 97-108.

Spahn, C.M., Beckmann, R., Eswar, N., Penczek, P.A., Sali, A., Blobel, G., and Frank, J. 2001. Structure of the 80 S ribosome from Saccharomyces cerevisiae-tRNA-ribosome and subunitsubunit interactions. Cell 107: 373-386.

Steinmetz, L.M., Scharfe, C., Deutschbauer, A.M., Mokranjac, D., Herman, Z.S., Jones, T., Chu, A.M., Giaever, G., Prokisch, H., Oefner, P.J., et al. 2002. Systematic screen for human disease genes in yeast. Nat. Genet. 31: 400-404.

Sugimoto, M., Kuo, M.L., Roussel, M.F., and Sherr, C.J. 2003. Nucleolar Arf tumor suppressor inhibits ribosomal RNA processing. Mol. Cell 11: 415-424.

Sulic, S., Panic, L., Barkic, M., Mercep, M., Uzelac, M., and Volarevic, S. 2005. Inactivation of S6 ribosomal protein gene in $\mathrm{T}$ lymphocytes activates a p53-dependent checkpoint response. Genes \& Dev. 19: 3070-3082.

Takagi, M., Absalon, M.J., McLure, K.G., and Kastan, M.B. 2005. Regulation of $\mathrm{p} 53$ translation and induction after DNA damage by ribosomal protein L26 and nucleolin. Cell 123: 49-63.

Tollervey, D., Lehtonen, H., Jansen, R., Kern, H., and Hurt, E.C. 1993. Temperature-sensitive mutations demonstrate roles for yeast fibrillarin in pre-rRNA processing, pre-rRNA methylation, and ribosome assembly. Cell 72: 443-457.

Tong, A.H., Evangelista, M., Parsons, A.B., Xu, H., Bader, G.D., Page, N., Robinson, M., Raghibizadeh, S., Hogue, C.W., Bussey, H., et al. 2001. Systematic genetic analysis with ordered arrays of yeast deletion mutants. Science 294: 2364-2368.

Tschochner, H. and Hurt, E. 2003. Pre-ribosomes on the road from the nucleolus to the cytoplasm. Trends Cell Biol. 13: 255-263.

Volarevic, S., Stewart, M.J., Ledermann, B., Zilberman, F., Terracciano, L., Montini, E., Grompe, M., Kozma, S.C., and Thomas, G. 2000. Proliferation, but not growth, blocked by conditional deletion of $40 \mathrm{~S}$ ribosomal protein S6. Science 288: 2045-2047. 
Warner, J.R. 2001. Nascent ribosomes. Cell 107: 133-136.

Wilson, D.N. and Nierhaus, K.H. 2005. Ribosomal proteins in the spotlight. Crit. Rev. Biochem. Mol. Biol. 40: 243-267.

Wilson, J.E., Powell, M.J., Hoover, S.E., and Sarnow, P. 2000. Naturally occurring dicistronic cricket paralysis virus RNA is regulated by two internal ribosome entry sites. Mol. Cell. Biol. 20: 4990-4999.

Wool, I.G. 1996. Extraribosomal functions of ribosomal proteins. Trends Biochem. Sci. 21: 164-165.
Yoo, Y.A., Kim, M.J., Park, J.K., Chung, Y.M., Lee, J.H., Chi, S.G., Kim, J.S., and Yoo, Y.D. 2005. Mitochondrial ribosomal protein L41 suppresses cell growth in association with p53 and p27Kip1. Mol. Cell. Biol. 25: 6603-6616.

Yoon, A., Peng, G., Brandenburger, Y., Zollo, O., Xu, W., Rego, E., and Ruggero, D. 2006. Impaired control of IRES-mediated translation in X-linked dyskeratosis congenita. Science 312: 902-906.

Yu, X. and Warner, J.R. 2001. Expression of a micro-protein. J. Biol. Chem. 276: 33821-33825. 

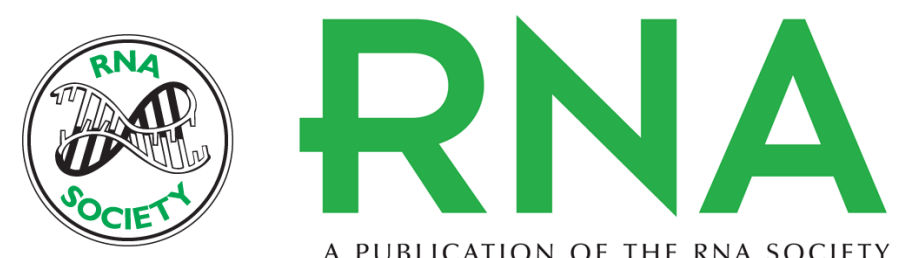

A PUBLICATION OF THE RNA SOCIETY

\section{Human ribosomal protein L13a is dispensable for canonical ribosome function but indispensable for efficient rRNA methylation}

Sujan Chaudhuri, Keyur Vyas, Purvi Kapasi, et al.

RNA 2007 13: 2224-2237

References This article cites 87 articles, 42 of which can be accessed free at:

http://rnajournal.cshlp.org/content/13/12/2224.full.html\#ref-list-1

License

Email Alerting Receive free email alerts when new articles cite this article - sign up in the box at the Service top right corner of the article or click here. 